\title{
Determination of acetylcholine receptor antibody in myasthenia gravis: clinical usefulness and pathogenetic implications
}

\author{
A. K. L E F V ER T, K. B ER G T T R Ö M, G. MA T E L L, \\ P. O. OSTERMA N, A N D R. PIR S K A N E N
}

From the Department of Clinical Chemistry, Karolinska sjukhuset and Myasthenia Gravis Center, Södersjukhuset, Stockholm, the Department of Neurology, Akademiska sjukhuset, Uppsala, Sweden, and the Myasthenia Gravis Center, Department of Neurology, University of Helsinki, Helsinki, Finland

SUMMARY Antibodies to cholinergic receptor structures were found in $75 \%$ of 76 Finnish and $93 \%$ of 175 Swedish patients with myasthenia gravis. The amount of antibodies showed a positive correlation to the severity of the disease, and was reduced during immunosuppressive treatment, and by thymectomy. Thymoma patients had high values. The antibody was also found in the cerebrospinal fluid. Two healthy newborn babies of myasthenic mothers had antibodies during the first weeks of life, in spite of no clinical symptoms. The occurrence of IgM antibodies before IgG antibodies in two patients during the early stages of myasthenia gravis suggests that the antibody is not a primary cause of the disease.

The typical muscular symptoms of myasthenia gravis have been attributed to a reduced effect of the neurotransmitter, acetylcholine, on the motor endplate (Grob et al., 1956). Theoretical arguments that myasthenia gravis might result from interference with the acetylcholine receptor by antibodies were first presented by Simpson (1960). During the last years experimental evidence has accumulated, pointing to the possibility that the disturbance of neuromuscular function is caused by an autoantibody directed against structures on the postsynaptic membrane of the neuromuscular junction.

In 1973 it was shown by retransfusion experiments that the myasthenic symptoms could be aggravated by a high molecular weight protein, probably an IgG (Bergström et al., 1973). In 1974 came the first report on the existence of a specific immunoglobulin, the acetylcholine receptor antibody, in the sera from the majority of patients with myasthenia gravis (Almon et al., 1974). These findings have now been confirmed by many other groups (Aharonov et al., 1975; Appel et al., 1975; Lindström et al., 1976; Lefvert and Bergström, 1977).

Address for reprint requests: Dr Ann Kari Lefvert, Department of Clinical Chemistry, Karolinska sjukhuset, S-10401 Stockholm, Sweden. Accepted 16 November 1977
A sensitive and accurate assay allowing quantitative determinations of acetylcholine receptor antibody has now been in routine use for two years in our laboratory. The aim of this study was to evaluate the clinical usefulness of receptor antibody determinations, and their possible implication on the pathogenetic mechanism of myasthenia gravis.

\section{Material and Methods}

PREPARATION OF PARTIALLY PURIFIED CHOLINERGIC RECEPTOR FROM HUMAN SKELETAL MUSCLE

Human skeletal muscle was collected from amputated legs at the time of operation. The muscle was immediately frozen and stored at $-80^{\circ} \mathrm{C}$. When used, the muscle was cut into small pieces and homogenised at $\pm 0^{\circ} \mathrm{C}$ in four volumes of phosphate buffer, $0.05 \mathrm{~mol} / 1$ with $\mathrm{NaCl}, 0.1 \mathrm{~mol} / 1$ and EDTA $0.001 \mathrm{~mol} / 1, \mathrm{pH} 7.5$ with the addition of Trasylol (Bayer AG, West Germany) to $10^{6}$ kallikrein inhibitory units/l. The homogenate was centrifuged at $30000 \mathrm{~g}$ for 20 minutes at $+4^{\circ} \mathrm{C}$, the pellet washed once, and resuspended in three volumes of the same buffer containing $1.5 \%$ Triton X-100. This mixture was stirred at room temperature for 90 minutes and then centrifuged at $30000 \mathrm{~g}$ for $20 \mathrm{~min}$ at $+4^{\circ} \mathrm{C}$. The lipid layer 
was discarded and the supernatant collected and stored in aliquots at $-80^{\circ} \mathrm{C}$. The ability to bind neurotoxin and acetylcholine-receptor antibody did not change during four months of storage.

The binding capacity for ${ }^{125} \mathrm{I}-\alpha$-neurotoxin (Naja naja siamensis) was determined by incubation of $1 \mathrm{ml}$ of the supernatant with different amounts of toxin at $+37^{\circ} \mathrm{C}$ for one hour, followed by gel filtration on Sephacryl G-200 superfine (Pharmacia Fine Chemicals, Sweden) to remove excess toxin. The recovery of toxin binding sites was 1-5 pmoles /g muscle (wet weight).

\section{IODINATION OF NEUROTOXIN}

Alpha-neurotoxin from the venom of Naja naja siamensis was kindly supplied by Professor E. Karlsson, Uppsala University, Sweden. The neurotoxin was labelled with ${ }^{125}$ I using the chloramin-T method (Hunter and Greenwood, 1962). About $30 \mathrm{nmoles}$ of neurotoxin $(225 \mu \mathrm{g})$ was dissolved in $10 \mu \mathrm{l}$ phosphate buffer $(0.01 \mathrm{~mol} / 1), \mathrm{pH}$ 7.2, containing $\mathrm{NaCl}(0.14 \mathrm{~mol} / \mathrm{l})$, and mixed with 20-50 $\mu$ l carrier free $\mathrm{Na}^{125} \mathrm{I}(1.5 \mathrm{mCi})$. Chloramin$\mathrm{T}$ solution $(50 \mu \mathrm{l} ; 3.6 \mathrm{mmol} / 1$ in phosphate buffer, $0.05 \mathrm{~mol} / \mathrm{l}, \mathrm{pH} 7.5$ ) was added, and the solution thoroughly mixed. After $60 \mathrm{~s}$ the reaction was terminated by addition of sodium metabisulphite solution $(100 \mu \mathrm{l} ; 53 \mathrm{mmol} / \mathrm{l}$ in phosphate buffer, $0.05 \mathrm{~mol} / 1 \mathrm{pH} \mathrm{7.5)}$ and potassium iodide solution ( $200 \mu \mathrm{l} ; 60 \mathrm{mmol} / 1$ in phosphate buffer, $0.05 \mathrm{~mol} / 1$, pH 7.5). The iodinated neurotoxin was separated from excess reagents by gel filtration on Sephadex G-25 (Pharmacia Fine Chemicals, Uppsala, Sweden).

The specific radioactivity was calculated to be $13 \mathrm{Ci} / \mathrm{mmol}$, assuming a quantitative recovery of protein during gel filtration. The labelled neurotoxin was stored in aliquots at $-80^{\circ} \mathrm{C}$.

\section{ASSAY FOR RECEPTOR ANTIBODY}

The amount of human skeletal muscle receptor preparation binding to IgG or IgM was measured by a method similar to that used by Appel et al. (1975), and by Lindström (1977). The cholinergic receptor preparation, 10-20 pmoles, was incubated for one hour at $+37^{\circ} \mathrm{C}$ with 200 pmoles of ${ }^{125} \mathrm{I}-\alpha-$ neurotoxin. The labelled toxin-receptor complex was separated from excess toxin by gel filtration on Sephacryl S-200 superfine at room temperature. The column $(25 \times 400 \mathrm{~mm})$ was equilibrated in phosphate buffer, $0.05 \mathrm{~mol} / 1$ with $\mathrm{NaCl}, 0.1 \mathrm{~mol} / 1$ and EDTA $0.001 \mathrm{~mol} / 1, \mathrm{pH} 7.4$, with Triton X-100, $0.5 \%$ and Trasylol to $10^{6}$ kallikrein inhibitory units/l. Subsequently, 0.2-0.5 pmoles of the toxinreceptor complex was incubated with $5 \mu 1$ of serum or plasina for 16 hours at $+4^{\circ} \mathrm{C}$. Rabbit-anti- human IgG or IgM (DACOPATTS A/S, Denmark) $300 \mu \mathrm{l}$, was added, and the tubes were allowed to stand for three hours at $+37^{\circ} \mathrm{C}$. The precipitate was separated by centrifugation in a Beckman minifuge (8000 $\mathrm{g}, 5$ minutes), and was washed once with $1 \mathrm{ml}$ of the same buffer. After alkaline hydrolysis and neutralisation the radioactivity (CPM) and protein content of the precipitate were determined. Several dilutions of each sample and of the normal plasma pool were analysed to make sure that the assay was linear in the range used. The amount of receptor antibody (a) compared to normal IgG (b) in the sample was then calculated according to $\mathrm{a} / \mathrm{b}=$

CPM for patient sample-CPM for normal plasma

CPM for normal plasma

The CPM value for the normal plasma was corrected to the same amount of IgG or IgM as the patient sample. The concentration of receptor antibody (arbitrary units/l) was then calculated as: (total concentration of $\operatorname{IgG} \times \mathrm{a} / \mathrm{b}: 10$ or total concentration of $\operatorname{IgM} \times a / b: 1$. This calculated value was related linearly to the amount of neurotoxinreceptor complex precipitated with myasthenic serum as calculated from CPM values. Different preparations of muscle receptor varied in their binding capacity for both neurotoxin and for receptor antibody. This difference was minimised by using the calculated value for receptor antibody concentration in arbitrary units/l. The normal plasma pool, which was the same in all experiments, was composed of plasma from 50 apparently healthy blood donors. Values above the upper $95 \%$ confidence limit of the normal pool were considered abnormal.

IMMUNOLOGICAL IgG DETERMINATION

These were made using an automated turbidimetric method. Rabbit antisera were obtained from DACOPATTS, Denmark. Standard Human Serum, stabilised, from Behringwerke AG, West Germany, was used as a standard. The antiserum, $600 \mu \mathrm{l}$, diluted $1 / 30$ in phosphate buffer, 0.05 $\mathrm{mol} / 1$, pH 7.4, with $\mathrm{NaCl}, 0.1 \mathrm{~mol} / 1$ and polyethylene glycol, MW $6000,90 \mathrm{~g} / 1$, was filtered $(0.2 \mu \mathrm{m})$ and then mixed with the sample, $25 \mu \mathrm{l}$, usually diluted $1 / 168$ in buffer without polyethylene glycol. The tubes were allowed to stand at room temperature for $45 \mathrm{~min}$. Blanks were prepared for each sample. The turbidity was measured at $340 \mathrm{~nm}$ using the LKB 2074 calculating absorptiometer (LKB, Sweden). The normal range for IgG using this method was found to be $7-15 \mathrm{~g} / 1$.

PROTEIN DETERMINATIONS

These were performed according to Lowry (Lowry 
et al., 1951) using human serum albumin (Kabi AB, Stockholm, Sweden) as a standard.

COLLECTION OF SAMPLES

Serum samples were frozen within a few hours and stored at $-20^{\circ} \mathrm{C}$ or preferably at $-80^{\circ} \mathrm{C}$ until analysed. Most samples were analysed within one or two months, and all samples from one patient were analysed on the same occasion.

CLINICAL CLASSIFICATION OF PATIENTS

The diagnosis of myasthenia gravis was confirmed by the typical case history, a positive response to edrophonium, and a typical response to repetitive nerve stimulation. Single fibre EMG was performed in about $75 \%$ of the Swedish patients (Stålberg and Ekstedt, 1973). The clinical evaluations of the patients were done at the time of blood sampling by three of us (GM, PO, and RP) using the same standardised inquiry form and standardised tests for muscle strength and physical performance (available on request from the authors). Functions were tested separately for eye muscles, bulbar muscles and the muscles of neck, legs, and arms, and graded, using a scale from 0-4 (0: no symptoms, $4:$ complete paralysis). The patients were classified by the modified criteria of Ossermann and Oosterhuis in the following stages (Oosterhuis, 1964):

A Complete remission

1 Ocular symptoms only

2A Mild generalised

2B Moderately severe generalised

3 Early severe

4 Late severe

Immunosuppressive treatment, thymectomy, and drainage of thoracic duct lymph were performed according to procedures reported elsewhere (Matell et al., 1976). Classification of thymus histology was performed in the routine pathological laboratories.

The statistical comparison of different groups of patients was made using both nonparametric methods-for example, the Wilcoxon test and the Kruskal-Wallis test-and ordinary analysis of variance, assuming heterogeneous variances. The results obtained with these methods were identical.

\section{Results}

About 800 sera from 251 patients from Finland and Sweden, 102 normal controls, and 124 patients with other muscular and autoimmune diseases were analysed.

In the control group (226 patients) only one borderline value was found (Table 1).

The distribution between Finnish and Swedish patients, the percentages of positive results and
Table 1 Acetylcholine receptor antibody concentration in a control group

\begin{tabular}{lll}
\hline & $\begin{array}{l}\text { Number of } \\
\text { patients }\end{array}$ & $\begin{array}{l}\text { Receptorantibody } \\
>0.2 \text { arbitrary } \\
\text { units } / l\end{array}$ \\
\hline Normal controls & 102 & 0 \\
Rheumatoid arthritis & 30 & 0 \\
Systemic lupus erythematosus & 25 & $1^{*}$ \\
Thymona without myasthenia & 3 & 0 \\
Polymyositis & 13 & 0 \\
Eaton-Lambert syndrome & 5 & 0 \\
Acute infectious diseases & 25 & 0 \\
Other diseases & 23 & 0 \\
\hline
\end{tabular}

*0.3 arbitrary units/1

Table 2 Acetylcholine receptor antibody in Finnish and Swedish myasthenia gravis populations

\begin{tabular}{llll}
\hline & $\begin{array}{l}\text { Number of } \\
\text { patients }\end{array}$ & $\begin{array}{l}\text { Positive results } \\
\text { receptor } \\
\text { antibody }>0.2 \\
\text { arbitrary units }\end{array}$ & $\begin{array}{l}\text { Mean } \pm 1 \text { SD of } \\
\text { positive samples } \\
\text { arbitrary units } / l\end{array}$ \\
\hline Finnish group & 76 & $75 \%$ & $2.00 \pm 2.05$ \\
Swedish group & 175 & $93 \%$ & $3.60 \pm 2.20$ \\
\hline
\end{tabular}

the means of acetylcholine receptor antibody concentration in the respective populations are shown in Table 2. The Finnish patients had significantly lower concentrations of the receptor antibody than the Swedish $(P<0.001)$.

Patients in the different clinical stages 1-4 also differed in receptor antibody concentration (Table $3)$. Patients in stage 4 had significantly higher values than all other groups $(P<0.001)$ whereas patients with pure ocular myasthenia had significantly lower values $(P<0.001)$. No difference, however, was found between patients in stage 1,2 , and 3 when only patients with a positive analysis were compared. No patient in stage 3 and 4 had a permanently negative analysis.

The correlation between the concentration of receptor antibody and the severity of clinical symptoms at the time of blood sampling was rather low, with a correlation coefficient for the whole material of 0.34 . The correlation was, however, much higher in the individual patient, where changes in symptoms very often coincided with changes in receptor antibody concentration. The level of receptor antibody tended to be constant in patients with no clinical change. This correlation between symptoms and antibody concentration was especially good during immunosuppressive treatment (Figs. 1 and 2). Both corticosteroids and azathioprine resulted in a decrease in receptor antibody concentration which was more pronounced than the decrease in normal IgG. During alternate-day treatment with corticosteroids the 
Table 3 Acetylcholine receptor antibody in different clinical stages of myasthenia gravis

\begin{tabular}{llccl}
\hline & $\begin{array}{l}\text { Stage of } \\
\text { disease }\end{array}$ & $\begin{array}{l}\text { Number of } \\
\text { patients }\end{array}$ & $\begin{array}{l}\text { Number of patients with receptor } \\
\text { antibody }<0.2 \text { arbitrary units } / l\end{array}$ & $\begin{array}{l}\text { Mean } \pm 1 \text { SD of positive samples arbitrary } \\
\text { units } / l\end{array}$ \\
\hline Finnish group & 1 & 7 & $2(29 \%)$ & $2.63 \pm 1.46(\mathrm{n}=5)$ \\
& 2 & 66 & $17(26 \%)$ & $1.92 \pm 2.18(\mathrm{n}=72)$ \\
Swedish group & $3+4$ & 3 & $0(0 \%)$ & $5.09 \pm 3.73(\mathrm{n}=5)$ \\
& 1 & 17 & $5(29 \%)$ & $2.61 \pm 2.38(\mathrm{n}=22)$ \\
& 2 & 118 & $11(9 \%)$ & $2.88 \pm 1.98(\mathrm{n}=336)$ \\
& 4 & 18 & $0(0 \%)$ & $4.04 \pm 2.40(\mathrm{n}=107)$ \\
& 4 & 18 & $0(0 \%)$ & $88)$ \\
\hline
\end{tabular}

Rec. ab.

arb. units/l

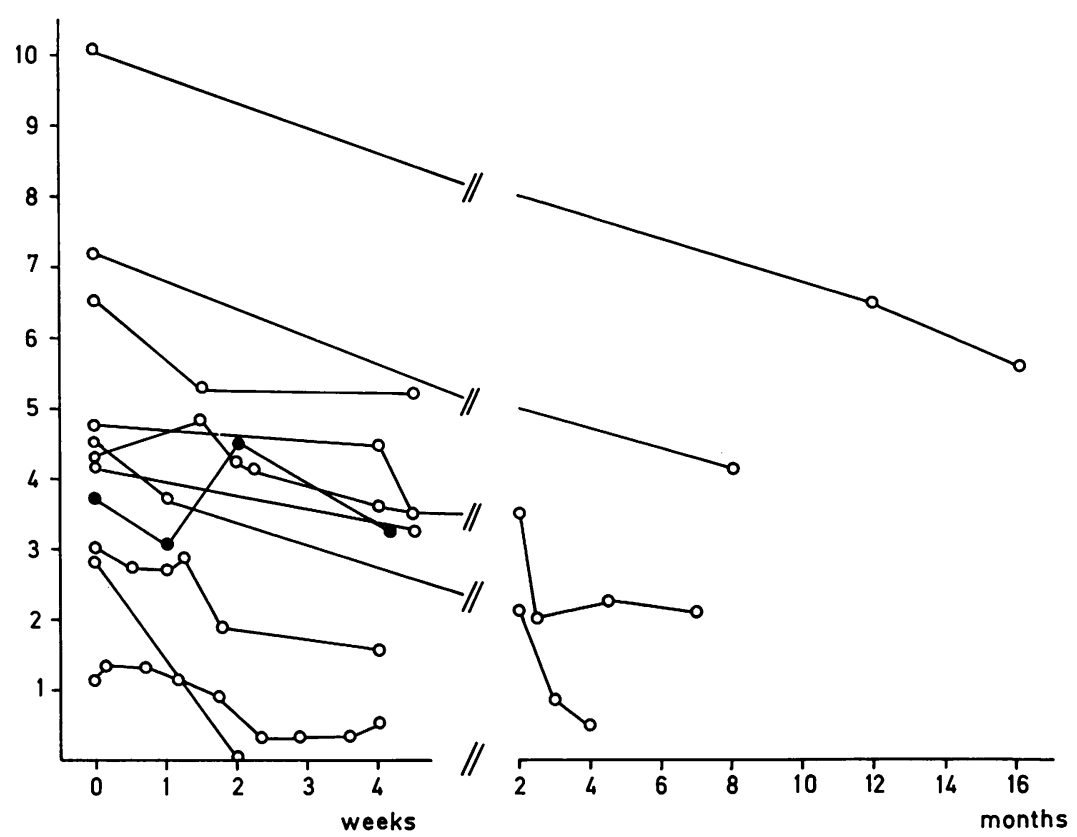

Fig. 1 Effect of treatment with corticosteroids on acetylcholine receptor antibody concentration and clinical symptoms, $\mathrm{-}-0=$ clinical improvement, $\bullet-\bullet=$ worsening or no clinical improvement.

usual pattern was a very fluctuating concentration of receptor antibody with variations between days which otherwise were not seen.

Drainage of thoracic duct lymph was followed by clinical improvement in four out of five patients (Fig. 3). In the one patient who did not improve, the decrease of receptor antibody concentration in serum was only $10 \%$ after one week. The amount of lymph drained was half to one-third of the total plasma volume per day for all patients. The decrease in receptor antibody concentration in serum ranged from 10 to $60 \%$. The reduction of total IgG, however, was more pronounced in all patients $(30-85 \%)$.
During treatment with ACTH four out of five patients showed a rise of receptor antibody concentration during the first week (Fig. 4). This rise coincided with the initial clinical worsening usually seen during ACTH treatment in myasthenia gravis, and was followed by a decrease in concentration. Patients on immunosuppressive treatment had significantly lower values of receptor antibody than patients without treatment $(P<0.001)$. When comparing only patients with a positive analysis, the difference between these groups was not significant $(P>0.05)$.

Thymectomy lowered the concentration of receptor antibody (Table 4). Swedish patients with 
Rec. ab.

arb. units/l

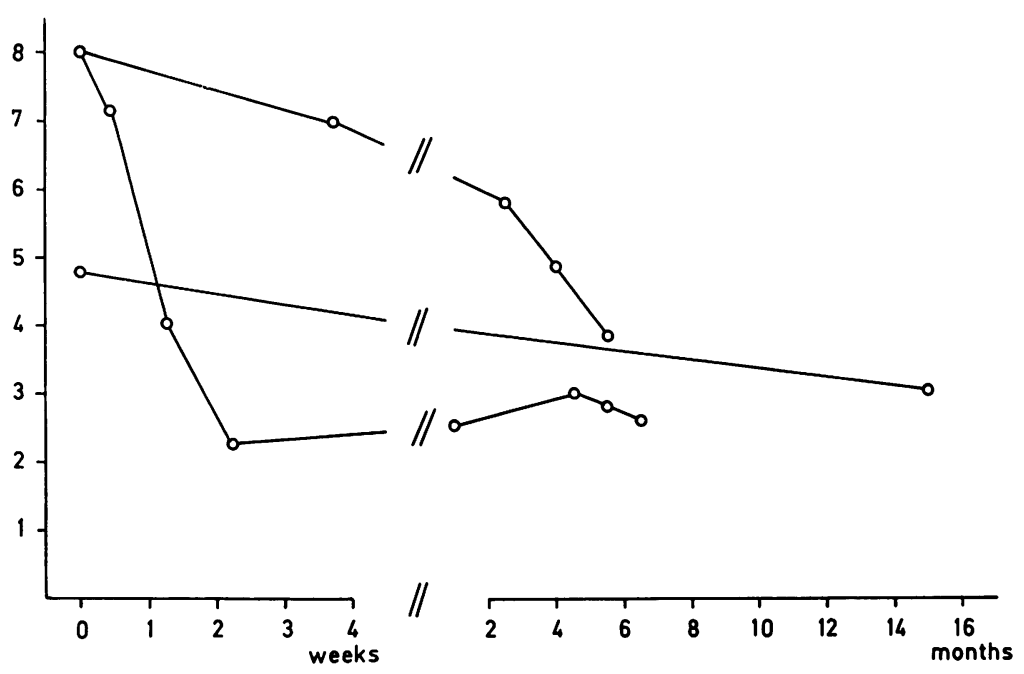

Fig. 2 Effect of azathioprine treatment, $\mathrm{O} \longrightarrow \mathrm{O}=$ clinical improvement.

Rec. ab.

arb. units/l

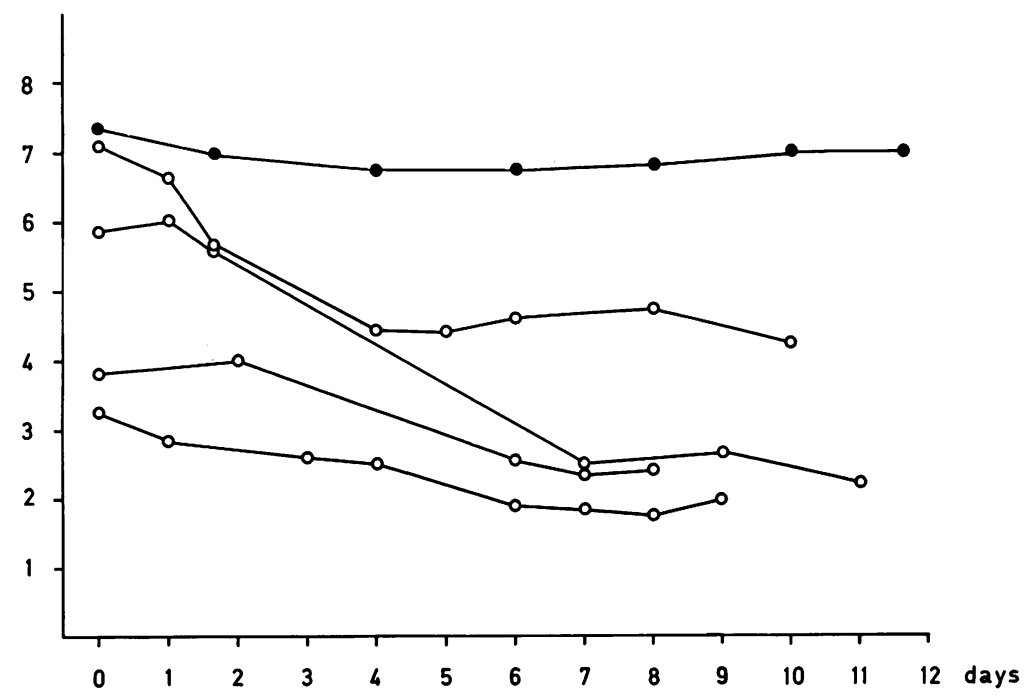

Fig. 3 Effect of thoracic duct lymph drainage, $\mathrm{O}-\mathrm{O}=$ clinical improvement, $\bullet-\bullet=$ worsening or no clinical improvement

normal thymus histology and with hyperplasia of the thymus had lower values after thymectomy than patients who had not been thymectomised $(P<0.001)$. The same tendency was present in the Finnish patients, but the difference between the groups was not statistically significant, possibly due to the small number of patients.

Thymoma patients not treated with immunosuppressive drugs had higher concentrations of receptor antibody even after thymectomy than had all the other groups $(\mathrm{P}<0.001)$. Among 20 patients who were operated upon for thymoma, no negative results were found. In this group there was also a marked difference between patients during immunosuppressive treatment (corticosteroids and azathioprine) and those not treated $(P<0.001)$. This difference was not seen in the other groups.

The duration of myasthenic symptoms before thymectomy and the time interval between thymectomy and the test did not correlate significantly 


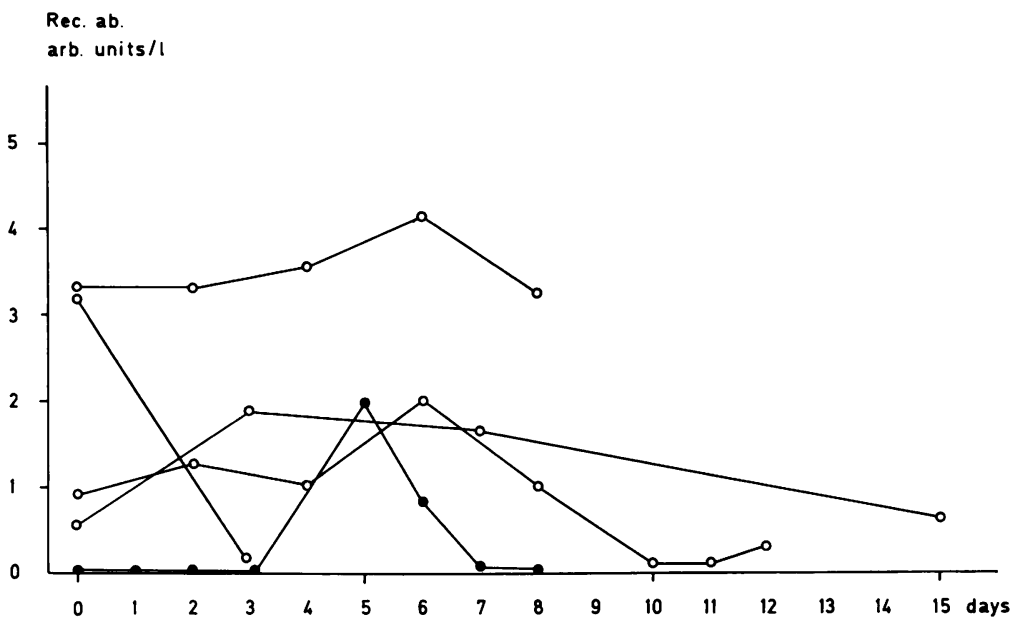

Fig. 4 Effect of $A C T H$ treatment, $\mathrm{O}-\mathrm{O}=$ clinical improvement, $\bullet-\bullet=$ worsening or no clinical improvement.

Table 4 Effect of thymectomy and different thymus histology on acetylcholine receptor antibody concentration

\begin{tabular}{|c|c|c|c|c|}
\hline $\begin{array}{l}\text { Thymus } \\
\text { histology }\end{array}$ & & $\begin{array}{l}\text { Number of } \\
\text { patients }\end{array}$ & $\begin{array}{l}\text { Number of patients with } \\
\text { receptor antibody }<0.2 \\
\text { arbitrary units } / l\end{array}$ & $\begin{array}{l}\text { Mean } \pm S D \text { of positive samples } \\
\text { arbitrary units/l }\end{array}$ \\
\hline \multicolumn{5}{|l|}{ Finnish group } \\
\hline No thymectomy & & 41 & $11(27 \%)$ & $2.07 \pm 2.20(n=45)$ \\
\hline Thymectomy & normal thymus & 10 & $2(20 \%)$ & $1.89 \pm 1.26(n=14)$ \\
\hline & hyperplasia & 22 & $6(27 \%)$ & $1.43 \pm 1.03(n=21)$ \\
\hline & thymoma & 3 & 0 & $4.41 \pm 5.62(n=3)$ \\
\hline \multicolumn{5}{|c|}{ Swedish group } \\
\hline \multirow{6}{*}{$\begin{array}{l}\text { No thymectomy } \\
\text { Thymectomy }\end{array}$} & & 42 & $2(5 \%)$ & $3.48 \pm 2.16(n=166)$ \\
\hline & normal thymus & 51 & $3(6 \%)$ & $\begin{array}{l}3.40 \pm 2.10(n=100) \\
2.68+1.75(n=141)\end{array}$ \\
\hline & hyperplasia & 45 & $3(7 \%)$ & $2.54 \pm 1.75(n=132)$ \\
\hline & thymoma & 17 & 0 & $3.38 \pm 2.00(n=101)$ \\
\hline & immunosuppressive treatment & & & $2.73 \pm 1.96(n=53)$ \\
\hline & no immunosuppressive treatment & & & $4.74 \pm 2.50(n=35)$ \\
\hline
\end{tabular}

with the concentration of receptor antibody in serum in any of the groups. Seven patients not treated with immunosuppression were followed before and after thymectomy (Fig. 5). Two of the patients did not improve after the operation, and in one of these the receptor antibody concentration rose after operation. In the other patients receptor antibody concentration decreased. Certain groups of patients had a high frequency of negative results (Table 5). Patients in complete remission and patients with ocular myasthenia had receptor antibody concentrations below 0.2 arbitrary units $/ 1$ in $44 \%$ and $29 \%$, respectively. In 10 out of 20 patients, the analysis was negative on at least one occasion during the course of immunosuppressive treatment. The other 10 patients all showed a reduction of the receptor antibody concentration. There were 13 Swedish and 19 Finnish patients with permanently negative analyses. Patients with ocular myasthenia, patients in complete remission, and patients treated with immunosuppressive drugs accounted for $62 \%$ and $37 \%$ in the Swedish and Finnish groups respectively.

No statistically significant difference in receptor antibody concentration was found in myasthenia gravis patients grouped according to sex, age, and duration of symptoms.

The concentration of receptor antibody and IgG was measured both in serum and in cerebrospinal fluid in 24 patients (Table 6). Of these, 17 patients had receptor antibody both in the cerebrospinal fluid and in serum. In one patient, receptor antibody could be found only in the cerebrospinal fluid and in one, only in the serum. The quotient between spinal fluid IgG concentration and serum IgG concentration as well as the IgG index [(CSF/S IgG ratio)/(CSF/S albumin ratio)] were normal in all but two cases. The quotient between the spinal fluid receptor antibody concentration and the serum receptor antibody concentration exceeded the corresponding value for IgG by a factor of $2-10$ in 11 out of 17 patients. 
Rec. ab.

arb. units/l

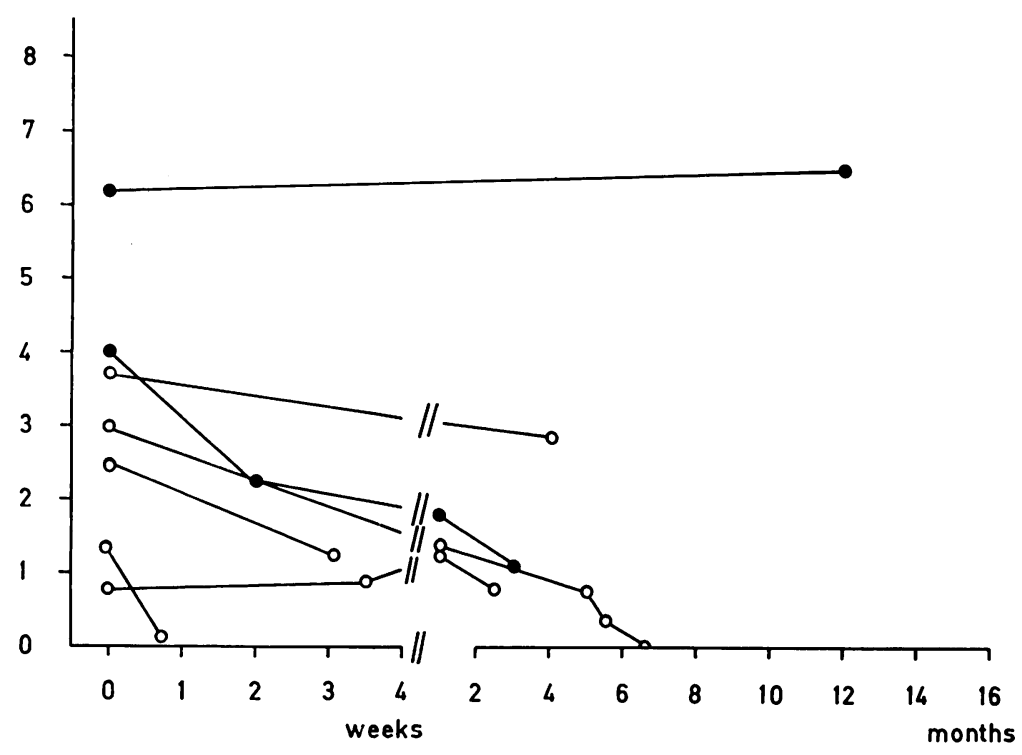

Fig. 5 Effect of thymectomy, $\mathrm{0}-\mathrm{O}=$ clinical improvement, $\bullet=$ worsening or no clinical improvement

Table 5 Patient groups with a high frequency of acetylcholine receptor antibody concentration below 0.2 arbitrary units/l

\begin{tabular}{lcc}
\hline Patient group & $\begin{array}{l}\text { Number of } \\
\text { patients }\end{array}$ & $\begin{array}{l}\text { Number of patients } \\
\text { with receptor antibody } \\
<0.2 \text { arbitrary units/l }\end{array}$ \\
\hline $\begin{array}{l}\text { Generalised myasthenia in } \\
\text { complete remission }\end{array}$ & 9 & \\
Ocular myasthenia & 24 & 4 \\
Immunosuppressive treatment & 20 & 7 \\
\hline
\end{tabular}

Samples were also analysed from two mothers with myasthenia gravis and from their newborn children. Both mothers had had mild generalised myasthenia gravis for four and seven years respectively, and one was in complete remission during pregnancy. No medication other than cholinesterase inhibitors was given to the other woman. Pregnancy and delivery were normal for both. The babies were clinically normal. The concentration of receptor antibody was followed in both babies during three weeks after birth (Table 7).

Receptor antibodies of the IgG type could be demonstrated in cord blood in both babies. The concentration in cord blood was equal to the concentration in maternal serum for one baby (S), and was about $30 \%$ higher for the other (P). Repeated examinations showed a fall in concentration to zero values within four weeks.
Table 6 Ratio of $C S F / S$ receptor antibody concentration to CSF/S IgG concentration in 17 patients

\begin{tabular}{ll}
\hline Patient & CSF-receptor antibody $/$ CSF-IgG \\
\cline { 2 - 2 } & S-receptor antibody $/ S$-IgG \\
\hline 1 & 4.48 \\
2 & 1.13 \\
3 & 2.88 \\
4 & 1.00 \\
5 & 0.75 \\
6 & 1.17 \\
7 & 2.57 \\
8 & 5.41 \\
9 & 2.61 \\
10 & 3.66 \\
11 & 2.22 \\
12 & 9.55 \\
13 & 3.45 \\
14 & 3.14 \\
15 & 0.75 \\
16 & 1.24 \\
17 & 7.72 \\
\hline
\end{tabular}

Table 7 Concentration of receptor antibody during the first month in two healthy children of myasthenic mothers

\begin{tabular}{lll}
\hline & Days after birth & $\begin{array}{l}\text { Receptor antibody } \\
\text { arbitrary units } / \text { l }\end{array}$ \\
\hline Baby P & 0 & 2.16 \\
& 1 & 2.06 \\
& 4 & 1.75 \\
Baby S & 30 & 0 \\
& 0 & 3.01 \\
& 2 & 2.30 \\
& 6 & 2.75 \\
\hline
\end{tabular}


All samples where no receptor antibodies of the IgG type could be found were also tested for the presence of antibodies of IgA and IgM type. In all but the five patients described below these analyses were negative.

On analysis of nine patients with a duration of symptoms less than nine months, three patients had receptor antibodies of the IgM type as well as of the IgG type (Fig. 6).

Two patients had an IgG receptor antibody concentration below 0.2 arbitrary units/ 1 when analysed three and six weeks, respectively, after the beginning of myasthenic symptoms. The concentration of IgM receptor antibody at this first examination was 0.27 and 0.22 arbitrary units/1 respectively. The upper $95 \%$ limit for the normal pool was 0.12 arbitrary units/l. The concentration of IgM antibodies decreased and that of IgG increased during the following months in both patients.

The third patient had both IgG and IgM type antibodies (3.00 and 0.35 arbitrary units/ 1 respectively). The concentrations did not change during an observation period of four months. In this patient the symptoms began six months before the first analysis.
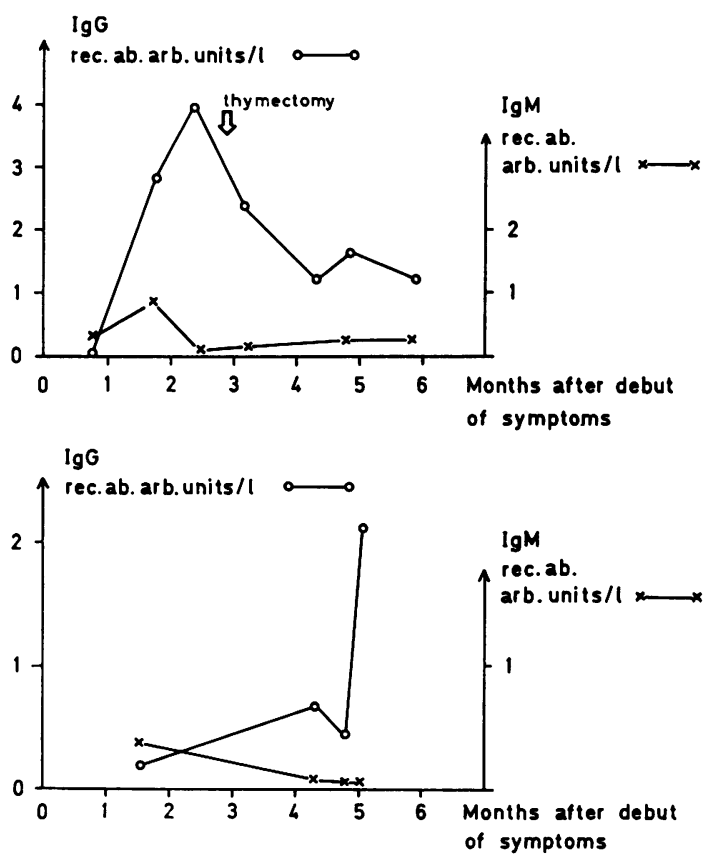

Fig. 6 Concentration of $\operatorname{IgM}(\mathrm{x})$ and $\operatorname{IgG}(\mathrm{o})$ receptor antibody in two patients with recent onset of myasthenic symptoms.
One patient with symptoms of four months duration had no receptor antibody of either IgM or IgG type. After one further month she had a rather high concentration of receptor antibody of IgG type only.

Two children, 2 and 10 years of age, with generalised myasthenia gravis had antibodies of IgG as well as of IgM type one year and two years after beginning of the myasthenic symptoms.

\section{Discussion}

In the last two years several authors have reported the occurrence of receptor antibodies in 85 to $95 \%$ of patients with myasthenia gravis. In the Swedish patients we found positive results in $93 \%$. The Finnish myasthenia gravis patients had significantly lower values. All samples were handled in the same way, and there was no difference in the time of storage before the analysis was performed. However, among the Finnish patients only three out of $76(4 \%)$ were in stage 3 or 4 , as compared with 36 out of $175(21 \%)$ in the Swedish group. This difference could not be explained by a different method of selecting patients for the study or by different classifications of the patients. The most probable explanation for the difference between the two populations seems to be that Finnish patients in general have a less severe disease, and this is also reflected in a lower concentration of receptor antibody. Another possible explanation might be genetic differences in antigen or antibody between the populations, since the muscle preparations were from Swedish patients.

Thymectomy was followed by a decrease in receptor antibody concentration within one or two months in most patients. Thymoma patients had higher values than all other groups (Lindström $e t$ $a l ., 1976)$ even five to 10 years after thymectomy. The occurrence of thymoma in myasthenia gravis is generally coupled with a more severe disease and a less favourable prognosis. Thymoma and a high concentration of receptor antibodies might both be caused by an unusually active immunological system. The marked decrease in receptor antibody concentration during treatment with immunosuppressive drugs could be explained by the relatively greater inhibitory effect on receptor antibody synthesis in these patients.

During lymph drainage the catabolism of IgG is increased but the synthesis is probably not affected (Strober et al., 1967). By using a mathematical model to analyse the kinetic behaviour of the different IgG fractions we could show that the half life of the receptor antibody in the three patients studied was two to three days, as com- 
pared with five to seven days for IgG subclass 3 , and 15 to 25 days for total IgG (Lefvert, submitted for publication). Two other patients had half lives for the receptor antibody of 0.9 and seven days, respectively. The patient with antibody half life of 0.9 days was the only one who did not improve during the drainage. The concentration of receptor antibody decreased only $10 \%$. Obviously, in this patient the synthesis of receptor antibody was so rapid that the increased catabolism during lymph drainage was almost fully compensated. The patient with an antibody half life of seven days had a complete remission, and was free from symptoms for more than one week after the period of drainage.

The great advantage of procedures such as lymph drainage and plasmapheresis is the rapid effect. But, considering the metabolic behaviour of the receptor antibody, it should be more effective to inhibit the synthesis than to try to deplete the antibody by protein drainage. In our patients, the removal of normal IgG was more efficient than the removal of receptor antibody during drainage. Treatment with corticosteroids and azathioprine, on the other hand, had a much greater effect on receptor antibody concentration than on the concentration of normal IgG.

As we have reported earlier (Lefvert and Pirskanen, 1977) most patients with receptor antibody present in serum also had the antibody in the cerebrospinal fluid. The increased quotient between spinal fluid and serum receptor antibody concentration as compared to the spinal fluid/ serum IgG quotient is evidence for local synthesis of receptor antibody. We have not yet been able to assess the clinical importance of this proposed local immunological reaction. The patients with high spinal fluid/serum receptor antibody quotient came from all groups and seemed to have no symptoms in common.

The report on neonatal myasthenia gravis by Keesey et al. (1977) describes the persistence of IgG receptor antibodies in a baby as long as four months after birth. This is in contrast to the rapid disappearance of receptor antibodies in our cases. In this study the two babies with receptor antibodies were free from myasthenic symptoms. This suggests that additional factors exist besides a passive transfer of maternal receptor antibodies. One explanation could be antigenic difference between the mother and the child. Another possible explanation involves a slight damage of receptor structures in the baby, triggering an occasional antibody synthesis. In our nonsymptomatic babies no IgM receptor antibodies were present.

The question of pathogenesis is of utmost interest in autoimmune diseases. Is the synthesis of autoantibodies a secondary phenomenon, triggered by structures already changed or damaged by some other mechanism, or is the autoantibody primarily responsible for the development of the disease? Regarding human myasthenia gravis no good evidence for pathogenetic mechanism has been presented.

In our material we had three patients with a short duration of myasthenic symptoms and no receptor antibody of IgG type when examined for the first time. Two of them had antibodies of IgM type. IgG antibodies appeared in all three patients during the following months, while the IgM antibodies decreased in concentration. This pattern of IgM and IgG antibodies is similar to that found during immunisation. These findings indicate that the synthesis of receptor antibody is triggered by antigenic stimuli, probably from damaged endplate structures, and that the antibodies are not a primary cause of myasthenia gravis.

\section{References}

Aharonov, A., Abramsky, O., Tarrab-Hazdai, R., and Fuchs, S. (1975). Humoral antibodies to acetylcholine receptor in patients with myasthenia gravis. Lancet, 2, 340-342.

Almon, K. R., Andrew, C. G., and Appel, S. H. (1974). Serum globulin in myasthenia gravis: Inhi- 8 bition of $\alpha$-bungarotoxin binding to acetylcholine receptors. Science, 186, 55-57.

Appel, S. H., Almon, R. R., and Levy, N. (1975). Acetylcholine receptor antibodies in myasthenia gravis. New England Journal of Medicine, 293, 760-761.

Bergström, K., Frankson, C., Matell, G., and von Reis, G. (1973). The effect of thoracic duct lymph drainage in myasthenia gravis. European Neurology, 9, 157-167.

Grob, D., Johns, R. J., and Harvey, A. M. (1956). Studies in neuromuscular function. IV stimulating and depressant effects of acetylcholine and choline in patients with myasthenia gravis, and their relationship to the defect in neuromuscular transmission. Bulletin of the Johns Hopkins Hospital, 99, 153-181.

Hunter, W. M., and Greenwood, F. C. (1962). Preparation of iodine ${ }^{131} \mathrm{I}$ labelled growth hormone of high specific activity. Nature (London), 194, 495-496.

Keesey, J., Lindström, J., Cokely H., and Herrman, C. (1977). Anti-acetylcholine receptor antibody in neonatal myasthenia gravis. New England Journal of Medicine, 296, 1-55.

Lefvert, A. K., and Bergström. K. (1977). Immunoglobulins in myasthenia gravis: effect of human lymph IgG 3 and $F\left(a b^{\prime}\right)_{2}$ fragments on a cholinergic receptor preparation from Torpedo marmorata. European Journal of Clinical Investigation, 7, 115119. 
Lefvert, A. K., and Pirskanen, R. (1977). Acetylcholine receptor antibodies in cerebrospinal fluid of patients with myasthenia gravis. Lancet, 2, 351-352.

Lindström, J. M., Seybold, M. E., Lennon, V. A., Whittingham, S., and Duane, D. D. (1976). Antibody to acetylcholine receptor in myasthenia gravis. Prevalence, clinical correlates and diagnostic value. Neurology (Minneapolis), 26, 1054-1059.

Lindström, J. (1977). An assay for antibodies to human acetylcholine receptor in serum from patients with myasthenia gravis. Clinical Immunology and Immunopathology, 7, 36-43.

Lowry, O. H., Rosebrough, W. J., Farr, A. L., and Randall, R. J. (1951). Protein measurement with the Folin phenol reagent. Journal of Biological Chemistry, 193, 265-275.

Matell, G., Bergström, K., Frankson, C., Hammarström, L., Lefvert, A. K., Möller, E., von Reis, G., and Smith, E. (1976). Effects of some immunosuppressive procedures on myasthenia gravis. Annals of the New York Academy of Sciences, 274, 659576.

Oosterhuis, H. J. G. H. (1964). Studies in myasthenia gravis. Part I. A clinical study of 180 patients. Journal of the Neurological Sciences, 1, 512-546.

Simpson, J. A. (1960). Myasthenia gravis: a new hypothesis. Scottish Medical Journal, 5, 419-436.

Strober, W., Wochner, R. D., Carbone, P. P., and Waldman, T. A. (1967). Intestinal lymphangiectasia. A protein-losing enteropathy with hypogammaglobulinemia, lymphocytopenia and impaired homograft rejection. Journal of Clinical Investigation, 46, 1643-1656.

Stålberg, E., and Ekstedt, J. (1973). Single fibre EMG and microphysiology of the motor unit in normal and diseased human muscle. In New Developments in Electromyography and Clinical Neurophysiology. Edited by J. E. Desmedt. Volume 1, pp. 113-129. Karger: Basel. 